\title{
The Pan-African nappe tectonics in the Shackleton Range
}

\author{
W. Buggisch ${ }^{1}$ and G. Kleinschmidt ${ }^{2}$ \\ ${ }^{1}$ Department of Geology, University Erlangen-Nürnberg, Schlossgarten 5, 91054 Erlangen, Germany, (buggisch@geol.uni-erlangen.de) \\ ${ }^{2}$ Institut für Geowissenschaften - JWG-Universität - FE Geologie - Altenhöferallee 1 - 60438 Frankfurt (kleinschmidt@em.uni-frankfurt.de)
}

Abstract In memory of Campbell Craddock: When J. Campbell Craddock (1972) published his famous 1:5000 000 map of the Geology of Antarctica, he established major units such as the East Antarctic Craton, the early Palaeozoic Ross, the Mesozoic Ellsworth, and the Cenozoic Andean orogens. It is already evident from this map, that the strike of the Ellsworth Mountains and the Shackleton Range is perpendicular to palaeo-Pacific and modern Pacific margins. While the Ellsworth-Whitmore block is classified as a rotated terrane, the Ross-aged orogen of the Shackleton Range requires another interpretation. The discovery of extended tectonic nappes with south directed transport in the southern Shackleton Range and west transport in the north established a plate tectonic scenery with a subduction dominated Ross Orogen in the Transantarctic Mountains and a transpressive tectonic regime in the Shackleton Range during the final closing of the Mozambique Ocean.

Citation: Buggisch, W. and G. Kleinschmidt (2007), The Pan-African nappe tectonics in the Shackleton Range: in Antarctica: A Keystone in a Changing World - Online Proceedings of the 10th ISAES, edited by A. K. Cooper and C. R. Raymond et al., USGS Open-File Report 2007-1047, Short Research Paper 058, 4 p.; doi:10.3133/of2007-1047.srp058

\section{Introduction}

This is a review paper concerning the nappe tectonics of the Shackleton Range, its history and its plate tectonic consequences. The Shackleton Range was discovered in December 1955 from an Argentine aircraft; a first ground survey was performed by Stephenson, Blaiklock and Stratton in 1957 (Clarkson, 1995). From 1968 until 1978 several British expeditions accomplished the basic knowledge of the geology of the Shackleton Range. Clarkson achieved special merits establishing and important progress in understanding the structure and plate tectonic position is the merit of Marsh (1983) who reported nappe(s) from the Read Mountains and correlated the deformation with an intra-Gondwana "Pan African" mobile belt. We were able to participate in two expeditions (GEISHA 1987/88 and EUROSHACK 1994/95) during which we could confirm the nappe tectonic concept.

\section{Southern Shackleton Range: Read Mountains}

The basement of the Read Mountains (Read Group)

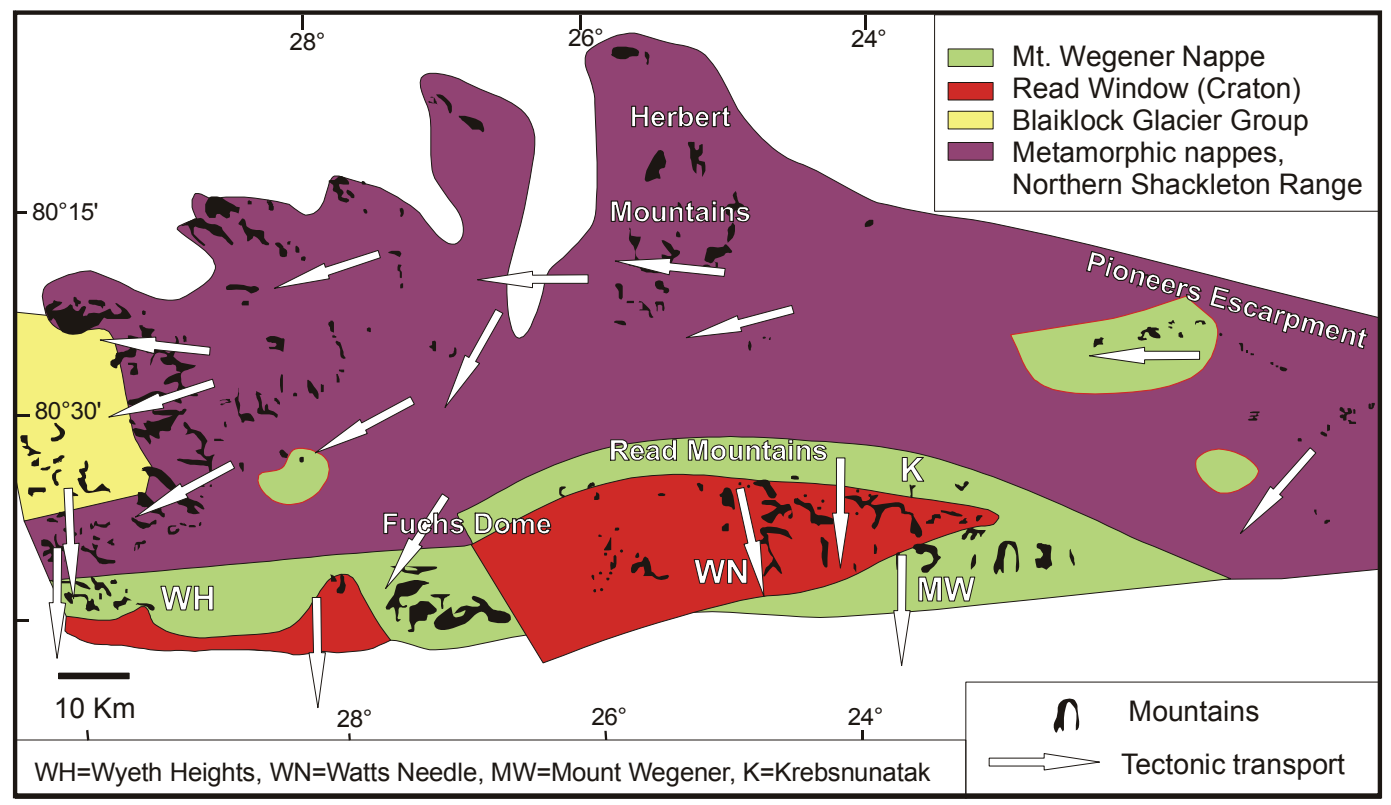

Figure 1. Simplified map of the Shackleton Range with directions of tectonic transport (from Kleinschmidt et al. 2002)

describing the important geological units of the Range (Clarkson, 1972; 1983). In 1976 - 1983 six Soviet expeditions were devoted to detailed geological sections and mapping (for summary see Clarkson et al., 1995). An consists of medium to high grade metamorphic rocks intruded by predominantly granitic to granodioritic plutons and minor basic to ultrabasic rocks (Olesch et al., 1995, Talarico and Kroner, 1999). This Archaean to 
Proterozoic Read Group is part of the East Antarctic Craton (Fig. 1). The craton was eroded to a peneplain before the deposition of the transgressive sequence of the Watts Needle Formation which consists of a basal regolith, followed by clean quartz sandstones, carbonates and shales (mudstones). The Watts Needle Formation is probably of late Precambrian (Riphaean to Vendian) age.
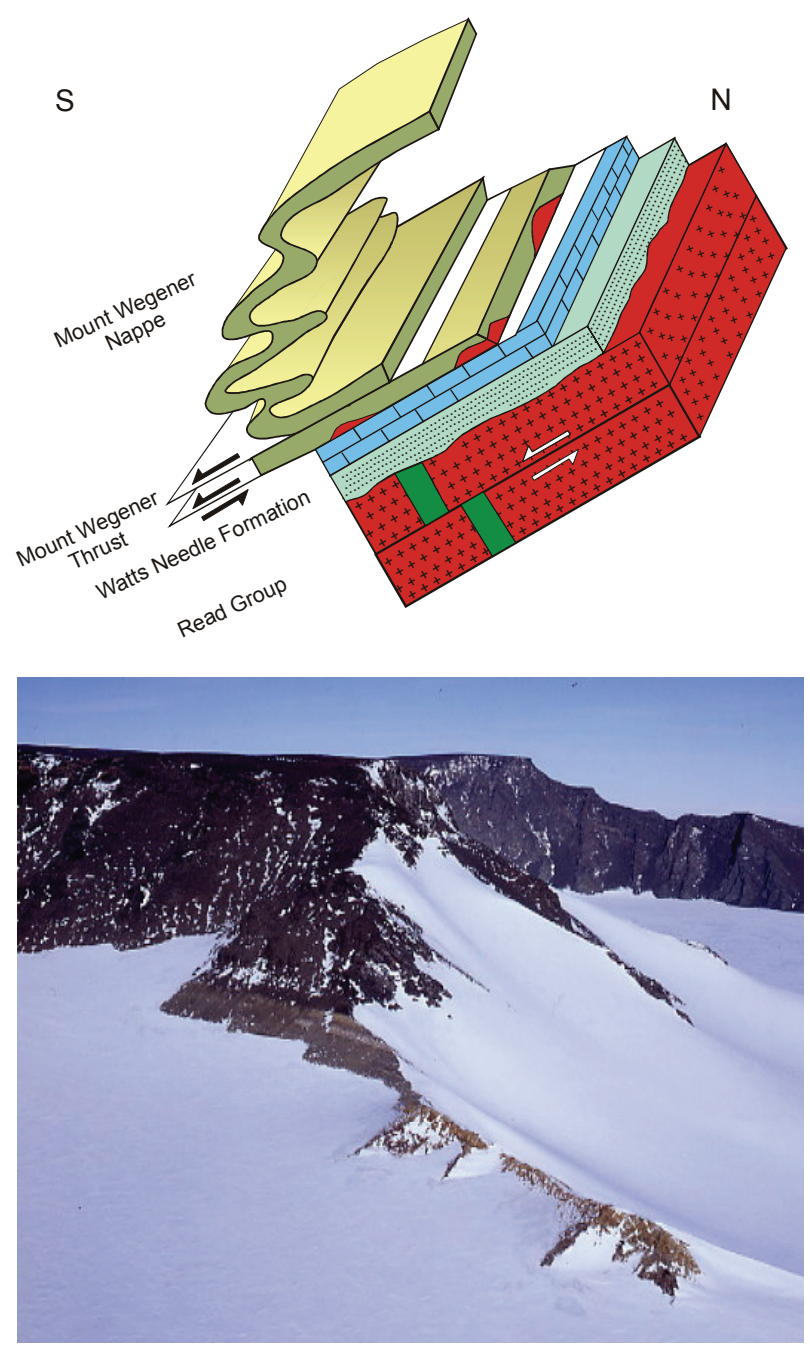

Figure 2. The Mount Wegener Thrust zone at Mt. Wegener.

The top of the Formation is cut off in all known sections by the basal thrust of the hangig Mount Wegener Nappe.

The Read Group and its sedimentary cover are exposed in a tectonic window framed by (very)low-grade metasedimentary rocks of the Mount Wegener Nappe. Slivers of crystalline rocks are incorporated in the basal thrust system of the nappe (Mount Wegener Thrust). The dip of the basal thrust is to the north in the Northern Read Mountains, flat in the center (Watts Needle) and to the south in the Southern Read Mountains (Mount Wegener). The metamorphic grade of the nappe is low (greenschist facies) in the north and very low in the south (Buggisch et al., 1994).

The nappe is composed of three Formations: The Proterozoic Stephenson Bastion Formation, the Early Cambrian Mount Wegener Formation with trace fossils (Oldhamia sp.) and archaeocyathids (Buggisch and Henjes-Kunst, 1999), and the Wyeth Heights Formation of unknown age which might be correlated with the Stephenson Bastion Formation.

.The best exposure of the southern frame of the Read Window is at Mount Wegener (Fig. 2). The east-west striking northern frame of the Read Window is exposed in several outcrops across the whole Shackleton Range. Representative sections through the basal Mount Wegener Thrust are found at Krebsnunatak and at the southernmost ridges of Wyeth Heights. The former outcrop exhibits alternating mylonitic augengneisses, metaconglomerates, metaarenites, and metapelites with growth of new biotite, dynamic and static recrystallization of quartz, but brittle deformation of feldspar (Fig. 3).

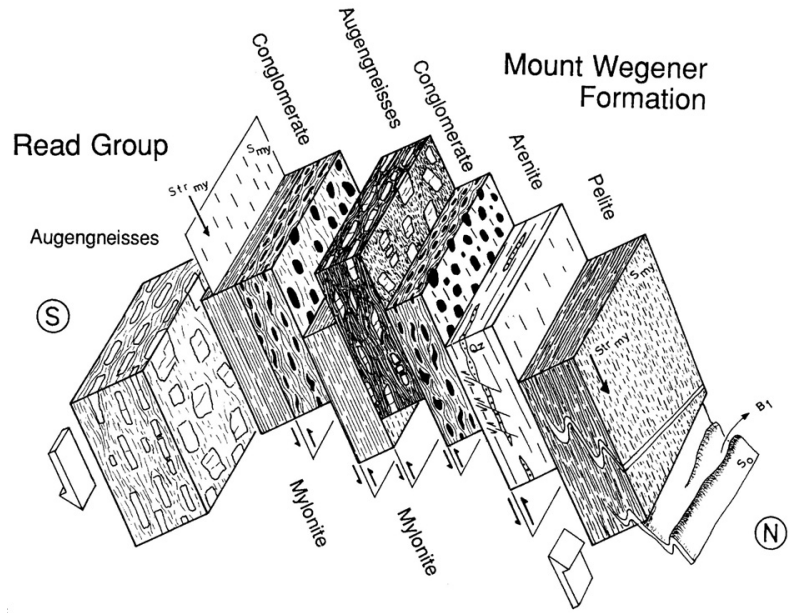

Figure 3. The Mount Wegener Thrust zone at Krebsnunatak.

At Wyeth Heights, limestones of the Watts Needle Formation are overthrust by slates to schists, metasandstones and quartzites of the Wyeth Heights Formation (Buggisch and Kleinschmidt, 1999). The limestones exhibit a strong mylonitic foliation and numerous shear sense indicators like stretched and distorted dolomite pebbles, $\delta-, \sigma-$, and book-shelf structures, all indicating southward transport of the hanging wall (Fig. 4). 


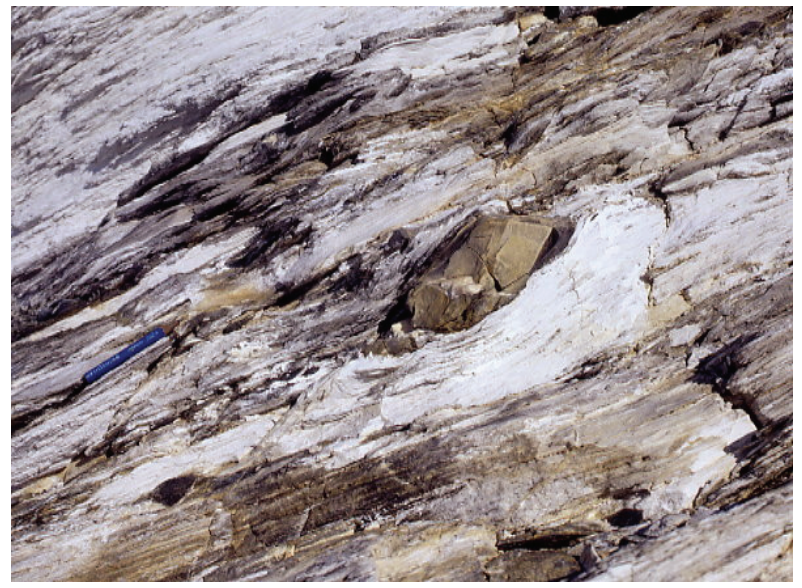

Figure 4. Dolomite $\sigma$-object in mylonitic limestones of the Watte Needle Formation south of Wyeth Heights. Central Shackleton Range.

The major part of the Central Shackleton Range is made up of medium to high grade metamorphic rocks. At least four inliers of low-grade sediments are observed. Conglomeratic quartzites crop out in the western Fuchs Dome and Bergan Castle, metaturbidites in the western Fuchs Dome and Pioneers escarpment areas. The conglomeratic, sometimes feldspathic quartzites can be compared with Mesoproterozoic rocks of the lower Stephenson Bastion Formation. The metapelites and metaarenites resemble Early Cambrian turbiditic sequences of the Mount Wegener Formation. Geochemical data of Kleinschmidt et al. (2001: Diagramm after Herron 1988 and $\varepsilon_{\mathrm{Nd}}$ ) support a correlation.

The four occurrences of low grade metasediments are interpreted to constitute tectonic windows of the Mount Wegener Nappe, framed by medium- to high-grade metamorphic rocks of the Central Shackleton Range.
Analyses of the structure revealed the following succession:

1. westward tectonic transport in the north and southwestward in the center during nappe formation.

2. N-S compression, refolding older structures.

3. late-orogenic collapse structures towards nearly all directions.

\section{The age of emplacement}

Sedimentation of the formations which make up the Mount Wegener Nappe lasted at least until Early Cambrian. K/Ar, and 40Ar/39Ar dating on mica separates of metasediments resulted in muscovite and biotite dates of 496 to $499 \mathrm{Ma}$ in the Central Shackleton Range (Kleinschmidt et al., 2001). Ages of 486 to $497 \mathrm{Ma}$ are determined for artificial grain-size fractions of 2-6 $\mu \mathrm{m}$ from the Mount Wegener Formation at the northern frame of the Read Window (Buggisch et al., 1994). Older dates of 508 to $547 \mathrm{Ma}$ from equivalent fractions of the southern frame represent mixed ages due to incomplete reset during very low grade metamorphism. Deformed rocks of the Central Shackleton Range are unconformably overlain by molasse-type Ordovician red-bed deposits of the Mount Provender Formation (Blaiklock Glacier Group). Mineral separate of sandstones and clasts of leucogneisses and granites gave $\mathrm{K} / \mathrm{Ar}$ and ${ }^{40} \mathrm{Ar} /{ }^{39} \mathrm{Ar}$ cooling ages of muscovite and biotite between 497 and $516 \mathrm{Ma}$ (Buggisch et al., 1999). Hence, emplacement of the nappes most probably took place during Late Cambrian times.

\section{Plate tectonic concept}

Although the age of deformation of the Shackleton Range corresponds to the age of the Ross Orogeny, the perpendicular strike of the Shackleton Range to the Ross
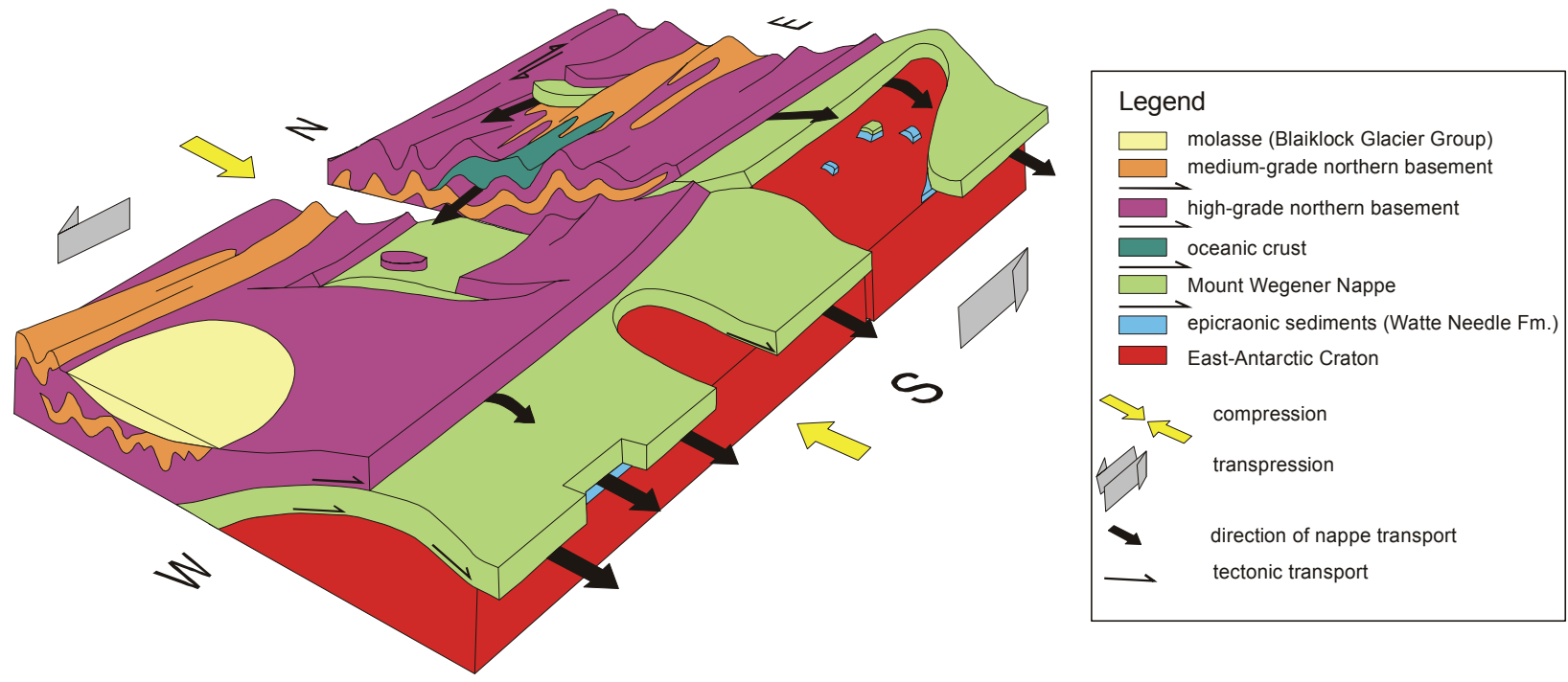

Figure 5. Scheme of nappe tectonics in the Shackleton Range (not to scale) 
Orogen of the Transantarctic Mountains requires a plate tectonic explanation (Fig. 5). The Ross Orogeny took place at the Palaeo-Pacific margin of the East Antarctic Craton and is mainly related to subduction (Goodge, 2007). The discovery of ophiolites which are incorporated in the pile of nappes in the Central Shackleton Range gives evidence for the existence of former oceanic crust (Talarico et al., 1999; Schmädicke and Will, 2006 ). Hence, the most probable scenario for the tectonic evolution of the Shackleton Range is:

A branch of the Mozambique Ocean - in a high angle to the Palaeo-Pacific Margin of the East Antarctic Craton - was closed during the late Pan-African Orogeny under a sinistral transpressive regime (Fig. 6). The resulting stress field was responsible for the westward tectonic transport in the northern Shackleton Range and the thrusting of the nappes over the East Antarctic Craton towards the south.

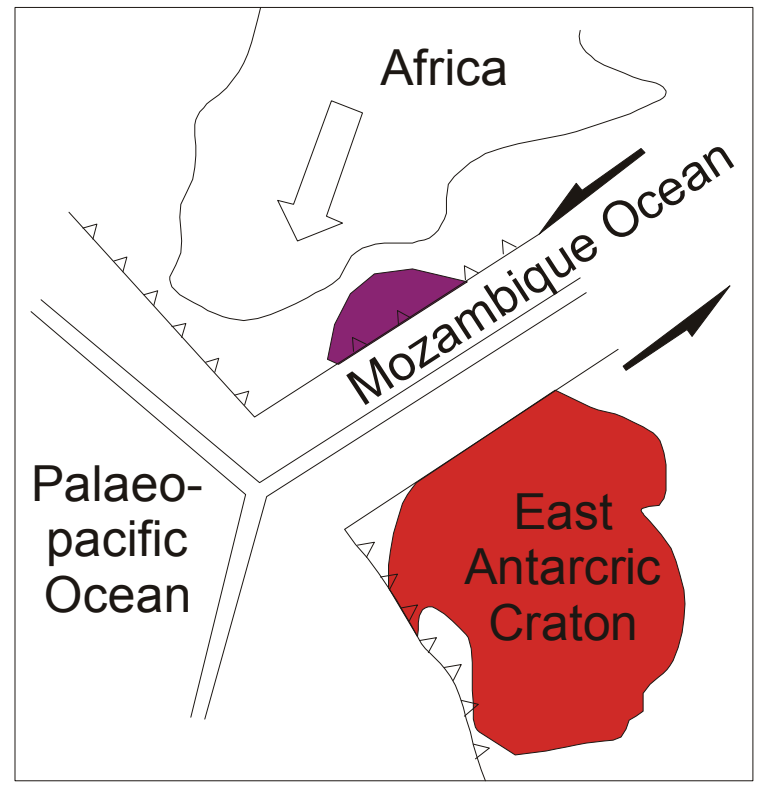

Figure 6. Hypothetical oceanic realm in the Shackleton Range (after Kleinschmidt et al., 2002; see also Tessensohn et al., 1999).

\section{Summary}

This paper is a review paper regarding the nappe tectonic of the Shackleton Range. It emphasizes the most important evidence for thrusts and tectonic transport. The age of deformation is limited by Lower Cambrian fossils in the Mount Wegener Nappe and by overlying Ordovician redbed deposits. K-Ar and Ar-Ar analyses of micas in rocks which suffered low-grade metamorphism during transport resulted in cooling ages of about $500 \mathrm{Ma}$. This age corresponds to the Ross Orogeny. From a platetectonic view, the transpressive tectonic is a result of the closure of a branch of the Mozambique Ocean and therefore a late Pan-African event.

Acknowledgments. We thank co-editor Wesley E. LeMasurier for his effort to publish this volume. Furthermore we appreciate the reviews of Franco Talarico (Siena) and Franz Tessenson (Hannover) which helped us to improve the manuscript. Financial and logistic support came from the German Science Foundation (DFG), the Alfred Wegener Institut (AWI) and the Bundesanstalt für Geowissenschaften und Rohstoffe (BGR) .

\section{References}

Buggisch, W., Bachtadse, V. and F. Henjes-Kunst (1999), Lithostratigraphy, Facies, Geochronology, and Palaeomagnetic Data from the Blaiklock Glacier Group, Shackleton Range, Antarctica. Terra Antartica, 6(3), 229-239.

Buggisch, W. and F. Henjes-Kunst (1999), Stratigraphy, facies, and provenance analyses of the Lower Cambrian Mount Wegener Pormation of the Shackleton Range, Antarctica, Terra Antartica, 6(3), 211-228.

Buggisch, W. and G. Kleinschmidt (1999), New evidence for nappe tectonics in the southern Shackleton Range, Antarctica, Terra Antartica, $6(3), 29-36$.

Buggisch, W., Kleinschmidt, G., Kreuzer, H. and S. Krumm (1994), Metamorphic and structural evolution of the southern Shackleton Range during the Ross Orogeny, Polarforschung, 63 (1, 1993), 33-56.

Clarkson, P. D. (1972), Geology of the Shackleton Range: a preliminary report, British Antarctic Survey Bulletin, 31, 1-15.

Clarkson, P. D. (1983), Geology of the Shackleton Range. II. The Turnpike Bluff Group, British Antarctic Survey Bulletín, 52, 109-124.

Clarkson, P.D. (1995): Introduction. In: Clarkson, P. D., Tessensohn, F., Thomson, J. W. and others (1995), Geological map of Shackleton Range, Antarctica. BASGEOMAP Series, Sheet 4, 1:250 000, Cambridge, British Antarctic Survey, 1-7.

Clarkson, P. D., Tessensohn, F., Thomson, J. W. and others (1995), Geological map of Shackleton Range, Antarctica. BAS GEOMAP Series, Sheet 4, 1:250 000, Cambridge, British Antarctic Survey, 79 p.

Craddock, C. (1972), Geological map of Antarctica 1: 5000 000, enclosure in Craddock, C. (ed.) (1982), Antarctic Geoscience, Madison (Univ. Wisconsin Press).

Goodge, J.W. (2007), Metamorphism in the Ross orogen and its bearing on Gondwana margin tectonics. Geological Society of America Special Paper, 419, 185-203.

Herron, M.M. (1988), Geochemical classification of terrigenous sands and shales from core or log data. J. sediment. Petrol., 58, 820-829.

Kleinschmidt, G., Buggisch, W., Läufer, A.L., Helferich, S. and F. Tessensohn (2002), The „Ross orogenic“ structures in the Shackleton Range and their meaning for Antarctica, Royal Soc. New Zealand Bull., $35,75-83$

Kleinschmidt, G., Henjes-Kunst, F. and F. Tessensohn (2001), Nappe tectonics in the central Shackleton Range, Antarctica. Z. dt. geol. Ges., $152(2-4), 227-248$

Marsh, P. D. (1983), The Late Precambrian and Early Palaeozoic history of the Shackleton Range, Coats Land., In Oliver, R. L., James, P.R. and J.H. Jago (eds.), Antarctic Earth Science, 190-193, Canberra.

Olesch, M., Braun, H.-M., Kmenenv, E.N., Kameneva, G.I. And W. Schubert (1995), Read Group. In: Clarkson, P. D., Tessensohn, F., Thomson, J. W. and others (1995), Geological map of Shackleton Range, Antarctica. BAS GEOMAP Series, Sheet 4, 1:250 000, Cambridge, British Antarctic Survey, 8-13.

Schmädicke, E. and T.M. Will (2006), First evidence of eclogite facies metamorphism in the Shackleton Range, Antarctica: Trace of a suture between East and West Gondwana? Geology, 34 (3), 133-136.

Talarico, F. and U. Kroner (1999), Geology and tectono-metamorphic evolution of the Read Group, Shackleton Range: a part of the Antarctic Craton, Terra Antartica, 6 (3), 183-202.

Talarico, F., Kleinschmidt, G. and F. Henjes-Kunst (1999), An ophiolitic complex in the northern Shackleton Range, Antarctica, Terra Antartica, $6(3 / 4), 293-315$.

Tessensohn,F., Kleinschmidt, G., Talarico, F., Buggisch, W., Brommer, A., Henjes-Kunst, F., Kroner, U., Millar, I.L. and A. Zeh (1999), Rossage amalgamation of East and West Gondwana: Evidence from the Shackleton Range, East Antarctica. Terr a Antartica, 6 (3), 317-325 